\author{
Office of Naval Research \\ DEPARTMENT OF THE NAVY \\ Contract N6onr-24420 (NR 062-059)
}

\title{
A PHOTOELASTIC STUDY OF STRAIN WAVES CAUSED BY CAVITATION
}

G. W. Sutton

\author{
Hydrodynamics Laboratory \\ CALIFORNIA INSTITUTE OF TECHNOLOGY \\ Pasadena, California
}

Report No. 21-21

Approved by:

October. 1955

M. S. Plesset 
Department of the Navy

Office of Naval Research

Contract N6onr-24420 (NR 062-059)

\title{
A PHOTOELASTIC STUDY OF STRAIN WAVES \\ CAUSED BY CAVITATION
}

\author{
George W. Sutton
}

\begin{abstract}
Reproduction in whole or in part is permitted for any purpose of the United States Government
\end{abstract}

Hydrodynamics Laboratory California Institute of Technology

Pasadena, California 



\begin{abstract}
ABST RACT
Ultra-high-speed photoelastic techniques have been applied to a study of the transient stresses and strains in a photoelastic plastic when subject to cavitation. A photocell, used to detect the transient strains, indicated that the time duration of the strains was about 2 microseconds. Using an ultra-high-speed motion picture camera, ultrasonic cavitation bubbles have been photographed collapsing on the surface of a photoelastic specimen, and the resulting strain wave in the solid has been photographed.

The dynamic properties of a photoelastic material have been obtained in order to permit quantitative interpretation of the transients. This has indicated that the stresses due to cavitation may be as high as $2.8 \times 10^{5}$ psi.

The photoelastic plastic, CR-39, was found to exhibit strain birefringence, and its strain-optic constant was found to be independent of the rate of loading.
\end{abstract}





\section{INTRODUCTION}

Although the laws governing the gross behavior of cavitation are well established, the study of the microscopic details of the vapor bubble history and surface damage has been retarded by a lack of experimental techniques with adequate time resolution. Recently, acoustical methods of concentrating the vapor bubble cloud on a small area of surface and an ultra-high-speed motion picture camera have been developed by Dr. Albert T. Ellis ${ }^{1,2}$ at the Hydrodynamics Laboratory of the California Institute of Technology. The shutter of this camera is a Kerr cell with crossed Polaroids on each side. This suggested immediately that the transient stress and strains due to cavitation could be investigated with photoelastic techniques. However, the laws concerning dynamic photoelasticity had not yet been accurately established; consequently, as a first step, a common photoelastic plastic, CR-39, was selected to make a comprehensive quantitative study of its static and dynamic photoelastic behavior.

\section{STATIC PROPERTIES OF CR -39}

It appeared advisable to determine the static properties of CR-39, for two reasons: first, to verify our experimental techniques by comparing the results of a static study with other similar studies; and second, to compare the static properties with the dynamic properties.

CR - 39 was selected as the photoelastic plastic because of its availability and because a considerable amount of experience on its fabrication has been obtained at the Guggenheim Aeronautical Laboratory at the California Institute of Technology. CR-39 is a thermosetting polymer of allyl diglycol carbonate manufactured by the Cast Optic Corporation of Riverside, Conn., and according to Coolidge ${ }^{3}$,

"Essentially, its manufacture consists of reacting phosgene with diethylene glycol to obtain a chloroformate which is then esterified with allyl alcohol to produce the diglycol carbonate monomer. This monomer is polymerized by heating in the presence of a catalyst such as benzoyl peroxide to form the 
hard, strong, infusible, insoluble, clear, substantially colorless substance known as CR-39. The commercially obtainable sheets of CR-39 are cast-polymerized between glass plates producing optically beautiful surfaces."

\section{A. Experimental Procedure}

The static tests were made on a simple tensile specimen with a working section 0.252 inches thick, 0.500 inches wide, and 3 inches long. Baldwin A-8 wire strain gages, which are limited to strains up to $1 \%$, were cemented to the front and back of the specimen in both the longitudinal and transverse directions. The strain was indicated directly by a Baldwin-Foxboro portable strain indicator which could be read to within 10 microinches. The strain gage constant was checked by comparing the wire strain gages against two calibrated Huggenberger mechanical extensometers.

The specimen was placed in the spherical mirror polariscope designed by Goetz ${ }^{4}$, for which the light source is a low pressure mercury vapor lamp, used with a Wratten $77 \mathrm{~A}$ filter to produce monochromatic light of $5461 \AA$ wave length. The fringe order in the specimen was determined by a calibrated Babinet-Soleil compensator that could be read easily to within 1/100 of a fringe line with only visual observation.

Creep tests were made by applying constant loads to the specimen for 180 minutes during which time the strain and fringe order were determined; the load was then removed and readings were made for another 180 minutes.

B. Results

Figure 1 shows the indicated strain for a typical creep test, where it is evident that CR-39 is viscoelastic. Figure 2 shows the ratio of stress, based on original area, to strain plotted as a function of time, where it is evident that the secant modulus decreases with both time and stress. Figure 3 shows stress vs. strain at 10 minutes after the application of load, at which time the Young's modulus is $3.36 \times 10^{5}$ psi.

Figure 4 shows the axial strain versus the transverse strain. For uniaxial stress, Poisson's ratio is given by the slope of the line, which 
is 0.443 .

Figure 5 shows the fringe order $N$ as a function of the difference in principal strains, from which it is evident that the birefringence of CR - 39 is proportioned to strain rather than to stress. The strain-fringe constant for plane stress, defined as

$$
G=\left(\epsilon_{1}-\epsilon_{2}\right) W / N \text {, }
$$

is $3.48 \times 10^{-4} \mathrm{in} /$ fringe, where $\epsilon_{1}$ and $\epsilon_{2}$ are the principal strains normal to the light path, $W$ is the width of the specimen, and $N$ is the fringe order.

Finally, in Fig. 6, the fringe order at the time of loading, as determined by extrapolation, is plotted against the product of stress and specimen width. The slope of this curve is the so-called stressoptic constant $F$, and is $90.8 \mathrm{psi-in/fringe.} \mathrm{This} \mathrm{value} \mathrm{decreases} \mathrm{with}$ time as the plastic creeps.

\section{Discussion}

Table I below is a summary of the author's date in comparison with the data by Coolidge ${ }^{3}$, and the manufacture ${ }^{\prime} s^{\prime}$ data. The procedure by which the manufacturer obtained the data is not known, but the reasons for the discrepancy with Coolidge's data is evident from an examination of his experimental techniques.

TABLE I - Static Properties of CR -39

\begin{tabular}{|c|c|c|c|}
\hline Property & $\begin{array}{l}\text { Manufacturer's } \\
\text { Data }\end{array}$ & $\begin{array}{l}\text { Coolidge's } \\
\text { Data }\end{array}$ & $\begin{array}{l}\text { Author's } \\
\text { Data } \\
\end{array}$ \\
\hline Tensile Strength, psi & $5000-6000$ & $7000^{*} 5$ & $-2---10$ \\
\hline Elastic Modulus, psi & $2.5-3.3 \times 10^{3}$ & $2.7 \times 10^{3}$ & 3. $76 \times 10$ \\
\hline $\begin{array}{l}\text { Poisson's Ratio } \\
\text { Strain Creep }\end{array}$ & $\begin{array}{l}--+--- \\
--n-n-\end{array}$ & yes & $\begin{array}{l}0.443 \\
\text { yes (see text) }\end{array}$ \\
\hline Specific Gravity & 1.31 & $---x--$ & 1.326 \\
\hline $\begin{array}{c}\text { Stress-Fringe Constant } \\
\mathrm{psi-in/fringe,} 5461 \mathrm{~A}\end{array}$ & 86.6 & $78.5^{* * *}$ & $90.8^{*}$ \\
\hline Optical Creep & none & $20 \% / 180 \mathrm{~min}$ & yes(see text) \\
\hline $\begin{array}{l}\text { Strain-Fringe constant, } \\
\mathrm{in} / \text { fringe }\end{array}$ & 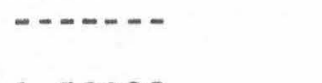 & ------- & $3.48 \times 10^{-4}$ \\
\hline Refractive index $N_{D}$ & 1.50398 & ----- & ------ \\
\hline
\end{tabular}

* Immediately after application of load.

** Stress was increased by increments to 4300 psi during 14 minutes; time between increments varied from one to two minutes. 
Coolidge determined the mechanical properties of CR-39 from a tensile specimen for which the load was increased every 10 minutes, but because CR -39 creeps, the elastic modulus thus obtained cannot be extrapolated to experiments in which the entire load is applied at one time. In addition, Coolidge determined a stress-fringe constant by applying incremental loads every one to two minutes, and using the definition of the stress fringe constant,

$$
F=\left(\sigma_{1}-\sigma_{2}\right) w / N
$$

where $\sigma_{1}$ is the axial stress, and $\sigma_{2}$ (in this case) was zero. The above comments also apply tothis procedure; but more important, his assumption that CR-39 is stress-birefringent is incorrect.

In passing, it should also be noted that Coolidge did observe a change in the fringe pattern with time in a beam subject to pure bending. In reducing this data, however, Coolidge used the Bernoulli beam equations and did not take into account either the strain-creep characteristics or the nonlinearity of CR-39; hence his data on the change of fringe order with time does not correspond to that of Fig. 1.

It should also be noted that two other plastics have been reported as strain birefringent, namely, polyethylene by Fried and Shoup 5 , and a special nylon by Hetènyi. ${ }^{6}$ No other correlations of birefringence to strain for plastics have been found in the literature by the author.

\section{DYNAMIC PROPERTIES OF CR-39}

The foregoing static properties of CR-39 cannot be extrapolated to make quantitative photoelastic observations of stress waves for two reasons. First, the dynamic strain-fringe constant may differ from the static value; for instance, Senior and Wells ${ }^{7}$ and Flynn ${ }^{8}$ measured the dynamic stress-fringe constants for several other plastics and found them to be higher than the static value. Second, since CR-39 is viscoelastic, the velocity of compressional and shear waves will depend on the wavelengths of the Fourier components of the wave, and in addition, 
the waves will become attenuated as they travel through the plastic. One way of describing this phenomena is to ascribe to the material a complex modulus which is a function of the wave length or the frequency of the Fourier components of the wave.

\section{A. Dynamic Mechanical Properties of CR -39}

It may be assumed that CR-39 is a Voigt solid at any one frequency. Then the stress-strain relationship may be expressed as follows:

$$
\sigma=E^{1} \epsilon+E^{\prime \prime} d \epsilon / d t
$$

where $\sigma$ and $\epsilon$ are the stress and strain respectively, $t$ is time, and $E^{\prime}$ and $E^{\prime \prime}$ are functions of the frequency $\omega$ of the applied strain; that is,

$$
\epsilon=\epsilon_{0} e^{i \omega t}
$$

Equation (3) then becomes

$$
\sigma=\left(E^{\prime}+i \omega E^{\prime \prime}\right) \epsilon
$$

Therefore $E^{\prime}+i \omega E^{\prime \prime}$ may be considered to be a complex modulus; that is,

$$
E^{*}=E^{\prime}+i \omega E^{\prime \prime}=E_{1}+i E_{2}=E e^{i \varphi}
$$

where

$$
\left.\begin{array}{rl}
E_{1} & =E \cos \varphi \\
E_{2} & =E \sin \varphi \\
\tan \varphi & =E_{2} / E_{1}
\end{array}\right\}
$$

For longitudinal stress waves in a bar, if the wave lengths are long in comparison to the thickness, Newton's law for a small element becomes

$$
\rho \frac{\partial^{2} u}{\partial t^{2}}=\frac{\partial \sigma}{\partial x}
$$

where $\rho$ is the mass per unit volume, $t$ is time, $x$ is the longitudinal coordinate of the bar, and $u$ is the longitudinal displacement; that is, 


$$
\epsilon=\partial u / \partial x \text {. }
$$

By substituting (5), (6) and (9) into (8), one obtains the following differential equation:

$$
\rho \frac{\partial^{2} u}{\partial t^{2}}=E e^{i \varphi} \frac{\partial^{2} u}{\partial x^{2}}
$$

When a bar of length $L$ is executing free-free longitudinal vibrations, Eq. (10) may be solved for its motion, which is

$$
u=\cos \left(\sqrt{\frac{E}{\rho}} \frac{\pi}{L} \cos \frac{\varphi}{2} t\right) e^{-\sin \left(\frac{\varphi}{2} \sqrt{\frac{E}{\rho}} \frac{\pi}{L} t\right)} \sin (\pi x / L) .
$$

It may be seen that the frequency $f$ and period of oscillation $\tau$ are given by

$$
\begin{aligned}
& f=\sqrt{\frac{E}{\rho}} \frac{1}{2 L} \cos \frac{\varphi}{2} \\
& \tau=\sqrt{\frac{\rho}{E}} \frac{2 L}{\cos \frac{\varphi}{2}}
\end{aligned}
$$

and the wave length $\Lambda$, wave speed c, logarithmic decrement $\delta$ are given by

$$
\begin{aligned}
& \Lambda=2 L \\
& c=f \Lambda=\sqrt{E / \rho} \cos (\varphi / 2) \\
& \sigma=2 \pi \tan (\varphi / 2) .
\end{aligned}
$$

As a given wave travels along the bar, it is attenuated as $e^{-a x}$; it may similarly be shown that the attenuation factor $a$ is given by

$$
a=\delta / \Lambda \text {. }
$$

The preceding constants were determined from free-free vibrations of various length bars of $\mathrm{CR}-39$, in which the strain was measured by Baldwin C-19 wire strain gages. For the shorter bars, a correction was 
made for the thickness, using data from experiments made by Morse ${ }^{10}$, and from a theoretical analysis by Bancroft. ${ }^{11}$ The results of the experiments on CR-39 are shown in Figs. 7, 8, and 9. From these, it is evident that with increasing frequency, the wave speed, logarithmic decrement, attenuation factor, and $E$ all increase. All dynamic values of $E$ are greater than any reported static values.

\section{B. Dynamic Strain-Fringe Constant}

Based on the correlation of the photoelastic fringe order to the strain, it appeared desirable to make similar measurements during transient stresses; that is, stresses caused by impacts. The dynamic loading apparatus is shown in Fig. 10 and a close-up of the specimen in Fig. 11. The procedure is to release a small hammer from the top of the loading frame, which then slides down a pair of vertical wires, and strikes the end of an aligned specimen of CR-39 which was 0.248 inches thick, 0.500 inches wide, and 10.75 inches long. Two Baldwin C-19 strain gages, the gage constant of which as given by the manufacturer was guaranteed to be within $3 \%$, were cemented on the specimen in the longitudinal direction, and two in the transverse direction.

By comparing the strain in the two directions during the passage of a stress wave, Poisson's ratio was found to be 0.44 , which is the static value within experimental error.

To determine the strain-fringe constant, the loading frame was placed in a polariscope and a monochromatic circularly-polarized light beam of $5461 \AA$ was directed through the space between the strain gages (see Fig. 12). The light intensity was detected by an IP 21 multiplier phototube whose output was amplified and displayed on one of the Tektronix oscilloscopes; the strain in the longitudinal direction was simultaneously detected by a bridge circuit similar to one used by Ripperger ${ }^{12}$, and displayed on the other Tektronix oscilloscope. Oscillograms were made with Dumont-Land oscillograph cameras. Figure 13 shows two such oscillograms, together with the fringe order, which is given by

$$
N(t)=\frac{1}{\pi} \sin ^{-1} \sqrt{I(t) / I_{0}}
$$


where $I_{0}$ is the peak light intensity, and $I(t)$ and $N(t)$ are the instantaneous light intensity and fringe order, respectively. The oscillograms are for the leading edge of the strain wave, the rise time of which was about 25 microseconds. The fringe order versus strain for the leading edge is shown in Fig. 14 and the slope, which is the strain fringe constant is $3.42 \times 10^{-4} \pm 3 \% \mathrm{in} /$ fringe. This value is the same as the static value within experimental error.

These tests also indicate that CR-39 is strain-birefringent rather than stress-birefringent, which is the usual relation used in photoelasticity. Note that both Eqs. (1) and (2) are valid for an elastic material, the birefringent constants being related by:

$$
\mathrm{F}=\mathrm{GE} /(1+v)
$$

and stress-birefringence cannot be distinguished from strain-birefringence in an isotropic solid subject to plane stress. However, plastics are viscoelastic to some extent; that is, $\mathrm{E}$ increases with increasing frequency, so that the dynamic value of $E$ is greater than the static value, the exact dynamic value depending upon the frequency components of the transient situation. Therefore, if a plastic is strain birefringent, the dynamic value of $F$ will be greater than the static value. This effect has been observed by other investigators, ${ }^{2} 8$ but unfortunately transient strains were not measured in those experiments. Hence, although those plastics are definitely not stress-birefringent, it cannot be concluded that they are strain-birefringent.

\section{TIME DURATION OF STRAINS DUE TO CAVITATION}

\section{A. Experimental Apparatus}

To study the strains caused by cavitation, the acoustic method devised by Ellis ${ }^{13}$ was used. The essential apparatus is shown in Fig. 15, and consisted of a glass beaker, a barium titanate ferroelectric ring surrounded by closed-cell sponge rubber, and a specimen holder, which in this case is a one-inch thick base of stainless stee1. A $1 / 16 \times 1 / 16$ $\mathrm{x} 1 / 8$ inch specimen of CR-39 was held in the center of the base, and the beaker was filled with distilled and deaerated water. 
The electrode surfaces of the barium titanate ring were connected to an audio-oscillator amplifier circuit, which excited the first mode of the oscillations of the water-base system when tuned to 22,000 cycles per second. The maximum pressure amplitude of the water is on the centerline of the beaker at the base. As the power to the barium titanate is increased, the minimum pressure during the negative part of the cycle drops below vapor pressure and cavitation forms on the upper surface of the specimen. The cavitation is visible in Fig. 15 in the form of a small bubble cloud.

The beaker was placed in a polariscope with a modified optical system so that a magnified image of the specimen was projected onto a screen in which a square hole was cut. In this way, only the light from an area 0.004 inch square on the specimen passed through the slit, the intensity of which was detected by an IP21 multiplier phototube, which was immersed in liquid nitrogen to reduce the noise level. The phototube output was amplified by a Tektronix Type 121 amplifier, and displayed on a Tektronix Type 513D oscilloscope. The frequency response of the amplifier is 12 megacycles and of the oscilloscope 18 megacycles. The frequency response of the phototube, as determined by light impulses through a Kerr cell of 0.08 microsecond duration was at least as high as that of the oscilloscope.

\section{B. Experimental Results}

The light slit was centered 0.006 inches below the upper surface of the CR-39 specimen. As the oscillator amplitude was increased, a distinct sine wave became visible on the oscilloscope, the frequency of which corresponded to that of the oscillator. As the oscillator was tuned to the lowest resonant frequency, 22, $000 \mathrm{cps}$, the wave form of the light intensity became distorted from sinusoidal toward a saw-tooth form. When the bubble cloud formed, a spike appeared on the oscilloscope screen, at the part of the cycle where the pressure becomes positive. Typical oscillograms are shown in Fig. 16. The spikes were present only when the bubble cloud was present. The lower oscillogram, a double exposure, shows that the time between spikes is not constant. The time duration of the spike was about 2 microseconds. When the slit was moved down away from the upper end of the specimen, or toward either 
side of the specimen, the spikes gradually decreased in amplitude, but the time duration of the spike remained constant. The amplitude of the spike corresponds to about one-quarter of a fringe-line, and was apparently insensitive to the bubble cloud size or amplitude of the exciting pressure cycle. It should be mentioned that the concentration of vapor bubbles seemed to be greatest at the center of the bubble cloud, just above the surface of the specimen.

Figure 17 shows photomicrographs of the top and sides of a specimen that had been subject to about 5 minutes of cavitation. There is a large irregular hole in the center, surrounded by individual holes which are about 0.001 inches in diameter.

The strain wave due to the cavitation did not exhibit the viscoelastic dispersion or dissipation that is typical of CR-39 at lower frequencies; this indicates the internal damping is negligible and the wave speed, and hence the elastic modulus, is approximately constant for the higher frequency components of the spike.

\section{ULTRA-HIGH-SPEED MOTION PICTURES}

\section{Experimenta1 Apparatus}

In order to photograph the transient isochromatic pattern due to the strains caused by cavitation, the ultra-high-speed motion picture camera developed by Ellis ${ }^{1}$ was utilized. This camera has a repetition rate up to one million frames per second for about a millisecond with a frame exposure of about 0.08 microsecond. Figure 18 shows the camera set up to photograph cavitation bubbles.

The camera is a revolving mirror type; the mirror distributes a series of images onto the inner periphery of a stationary drum in which a 7-1/2 foot length of $35 \mathrm{~mm} \mathrm{Tri-X} \mathrm{film} \mathrm{has} \mathrm{been} \mathrm{placed.} \mathrm{The} \mathrm{exposure}$ for each frame is achieved by a Kerr cell. The Kerr cell consists of a glass container, on the front and back of which are crossed Polaroids so that normally no light is transmitted through the cell. On either side of the cell are two flat electrodes spaced 0.25 inches apart; when a voltage difference of 13,000 volts exists across the electrodes, the 
nitrobenzene in the container becomes sufficiently optically active to rotate the plane of the light that had been polarized by the front polaroid so that it passes through the rear polaroid.

The Kerr cell is electrically pulsed for about 0.08 microseconds to achieve each frame, and is pulsed continuously only during one revolution of the mirror. During this revolution, a General Electric FT 524 flash tube is illuminated by discharging through it the energy stored in a bank of capacitors. Suitable inductances cause the light intensity to be almost constant for about a millisecond.

To photograph the strains due to cavitation, a slightly different cavitation beaker was used. A circularized light polariscope with a light background was used so that the entire field, including the cavitation bubbles, would be visible; specimens with thicknesses of $0.25,0.0625$, and 0.020 inch were used. The resonant frequency for this beaker was 10 kilocycles per second.

\section{Results}

Figure 19 shows a series of consecutive frames taken at 150, 000 frames per second of a 0.25 -inch thick specimen. The lower right-hand line represents the edge of the specimen; it is blurred because of the small depth of field of the lens. The other two dark lines are time-edge isochromatics, caused by leaving the specimen immersed in water for too long a period of time. However, they provided a sensitive means to detect fractional changes in the isochromatics due to transient strains. The twelfth frame shows a shift of about $1 / 4$ of a fringe just after the collapse of the bubble cloud. In addition, the entire specimen is also darkened. Only one frame is affected; this is caused by the short time duration of the transient and the large speed of propagation of the stress wave.

In subsequent runs, half a dozen cases of fringe shift just after bubble collapse were observed; this was also observed in the 0.0625 specimen, but not in the 0.020 specimen. When the fringe shift was observed, it always occurred in the immediate vicinity of the bubble collapse. These bubbles did not exhibit spherical symmetry; on the other hand, the affected area in the specimen was always spherical, centered below the 
last bubbles to collapse.

Because of the blurring of the edge of the specimen, it was not possible to determine photographically the initially strained area. How ever, it may be postulated that initially, the cavitation pressure acts only on the area corresponding to a small pit; that is, a diameter of 0.001 inch. It may be assumed that during the initial pulse, the lateral elongations are zero; then the observed fringe order is

$$
N=\frac{1}{G} \int \epsilon_{1} d x
$$

where $\epsilon_{1}$ is the strain normal to the surface. Now, for plane strain, the stress $\sigma_{1}$ normal to the surface is given by

$$
\sigma_{1}=\frac{(1-v) E \epsilon 1}{(1+v)(1-2 v)}
$$

where $v$ is Poisson's ratio. When $\epsilon_{1}$ is eliminated from Eqs. (19) and (20), the following expression is obtained for the average stress $\overline{\sigma_{1}}$ :

$$
\overline{\sigma_{1}}=\frac{1}{\mathrm{~d}} \int_{-\mathrm{d} / 2}^{+\mathrm{d} / 2} \sigma_{1} \mathrm{dx}=\frac{\operatorname{EGN}(1-v)}{\mathrm{d}(1+v)(1-2 v)}
$$

where $\mathrm{d}$ is the diameter over which the stress acts initially. The elastic modulus is not known accurately for ultra-high-frequency components, but to obtain an order of magnitude estimate of the average stress, it may be estimated as $10^{6}$ psi. With $G=3.42 \times 10^{-4}$ in/fringe $\mathrm{N}=1 / 4$ and $\mathrm{d}=0.001 \mathrm{inch}$, the average stress $\sigma_{1}$ is about $2.8 \times 10^{5} \mathrm{psi}$.

\section{CONCLUDING REMARKS}

The ultra-high-speed photoelastic techniques have yielded quantitative information on the time duration of stresses due to cavitation and the magnitude of the stresses. Additional study of the behavior of photoelastic materials at higher frequencies and stresses is required, as well as a method of direct calibration of axilly symmetric impacts. 
It also appears desirable to obtain better depth of field and magnification of the photographic image.

\section{ACKNOWLEDGMENTS}

The author wishes to express his appreciation to Professor M. S. Plesset and Dr. A. T. Ellis for their aid and guidance during this study. 

REFERENCES

1. Ellis, A. T., "Observations on Cavitation Bubble Collapse", California Institute of Technology, Hydrodynamics Laboratory Report No. 21-12, December, 1952.

2. Ellis, A.T., "Production of Accelerated Cavitation Damage by an Acoustic Field in a Cylindrical Cavity", California Institute of Technology, Hydrodynamics Laboratory Report No. 21-14, September, 1955.

3. Coolidge, D. J., Jr., "An Investigation of the Mechanical and Stress-Optic Properties of Columbia Resin, CR-39", S. E. S. A. Vol. VI, No. 1, pp. 74-82.

4. Goetz, A., "A Modified Optical Arrangement for Photoelastic Measurements", Rev. Sci. Instr., Vo1. 5, No. 2, (1934), p. 84 .

5. Fried, B., and Shoup, N.H., "A Study in Photoplasticity", TR No. 3, ONR Contract N7onr-330-III NR 064-121, State College of Washington, May 1953.

6. Hetenyi, M., "A Study in Photoplasticity", Proc. 1st U.S.

National Congress of Applied Mechanics, Ann Arbor, 1952, pp. 499-502.

7. Senior, D.A. and Wells, A.A., "A Photoelastic Study of Stress Waves", Phil. Mag., Vol. 7, (1946), pp. 463-469.

8. Flynn, P.D., "Studies in Dynamic Photoelasticity", PhD Thesis, Illinois Institute of Technology, 1954.

9. Kolsky, H., "Stress Waves in Solids", Oxford, 1953.

10. Morse, R.W., "Dispersion of Compressional Waves in Isotropic Rods of Rectangular Cross-section", J. Acous. Soc. Am., Vo1. 20, (1948), pp. 833-838.

11. Bancroft, D., "The Velocity of Longitudinal Waves in Cylindrica1 Bars", Phys. Rev., Vol. 59, (1941), pp. 588-593.

12. Ripperger, E. A., "Longitudinal Impact of Cylindrical Bars", S.E.S.A. Vol. 10, No. 1, pp. 209-226. 



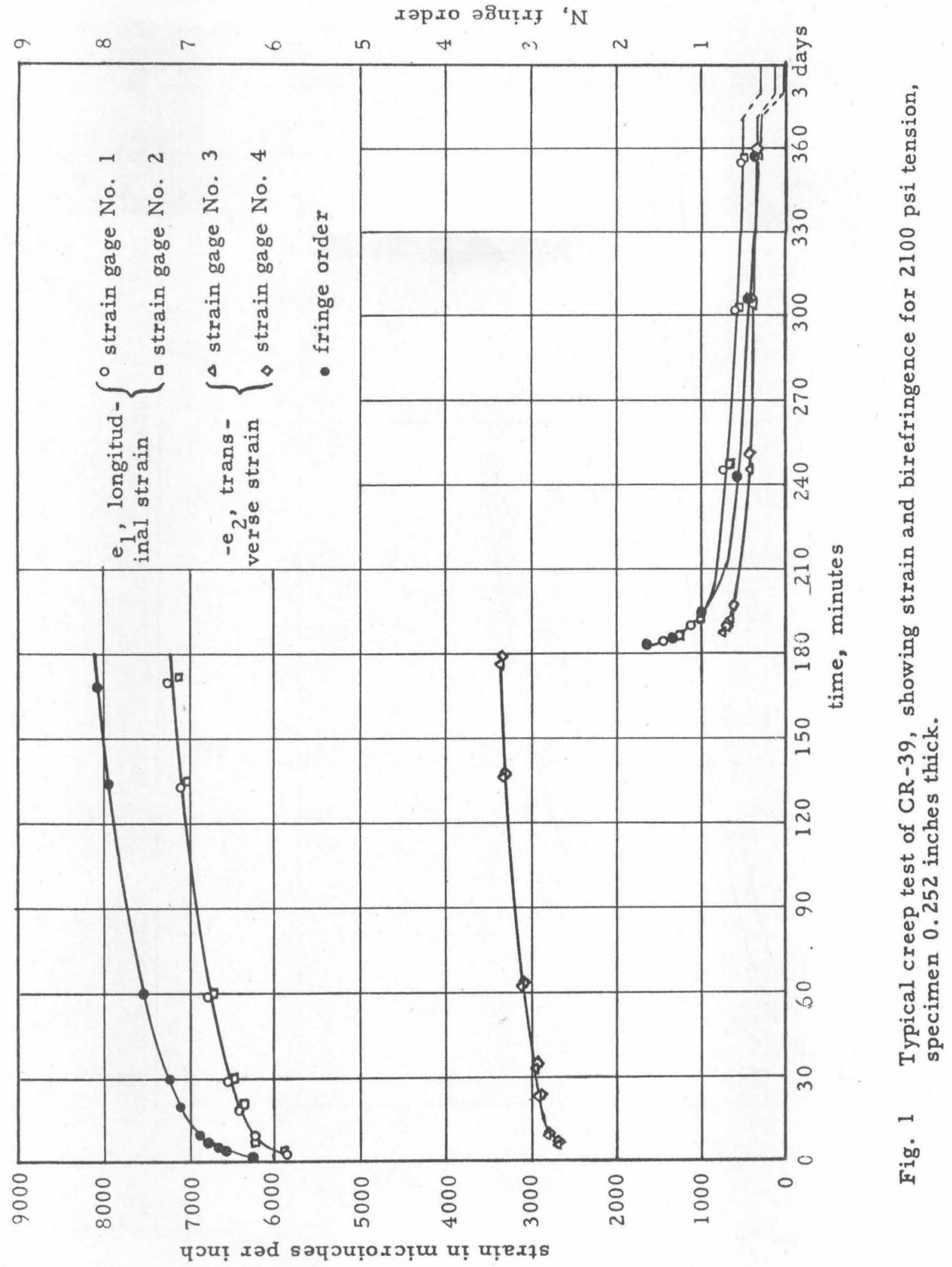




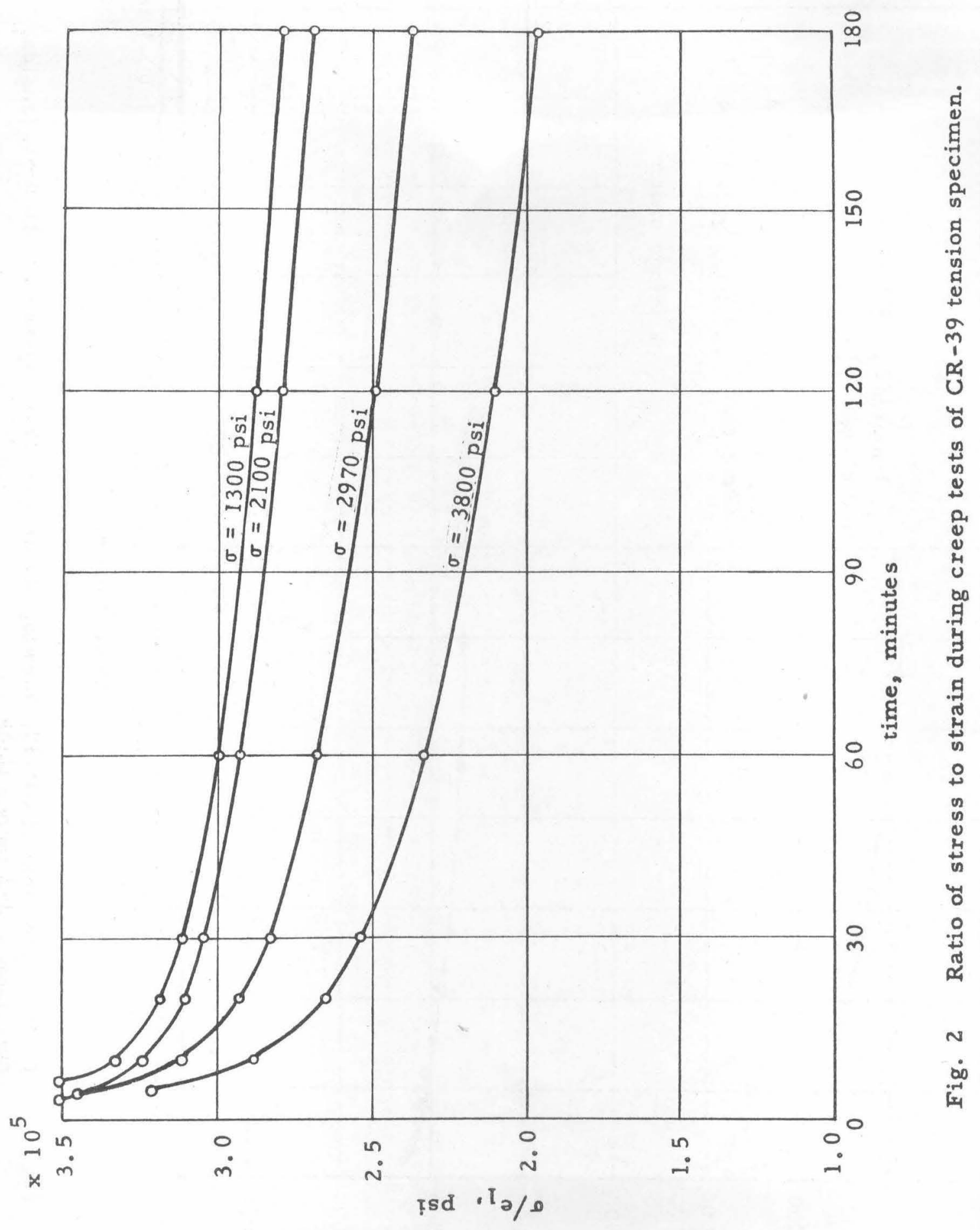




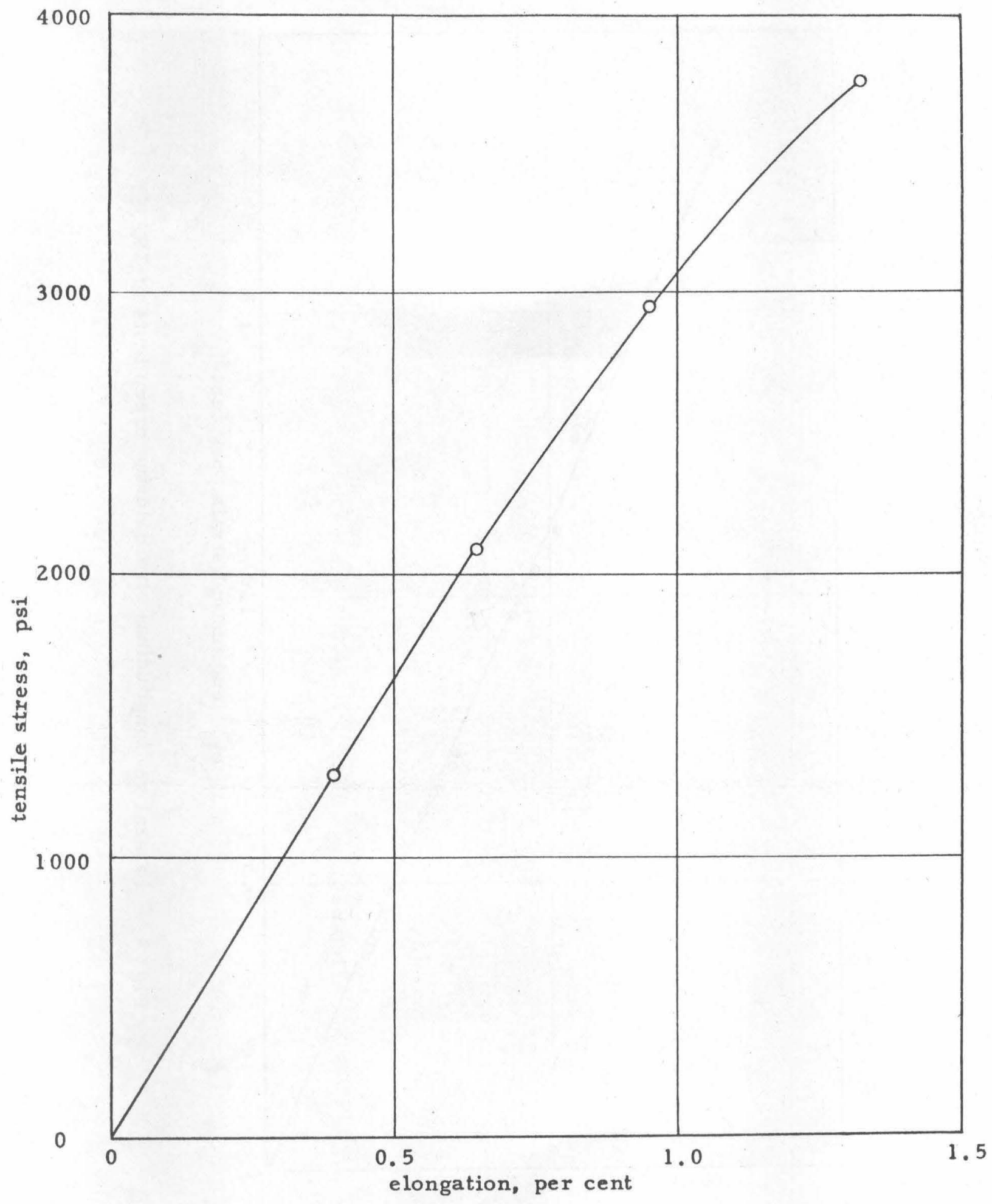

Fig. 3 Tensile stress vs. longitudinal strain after 10 minutes of creep for CR-39 tensile specimen. 


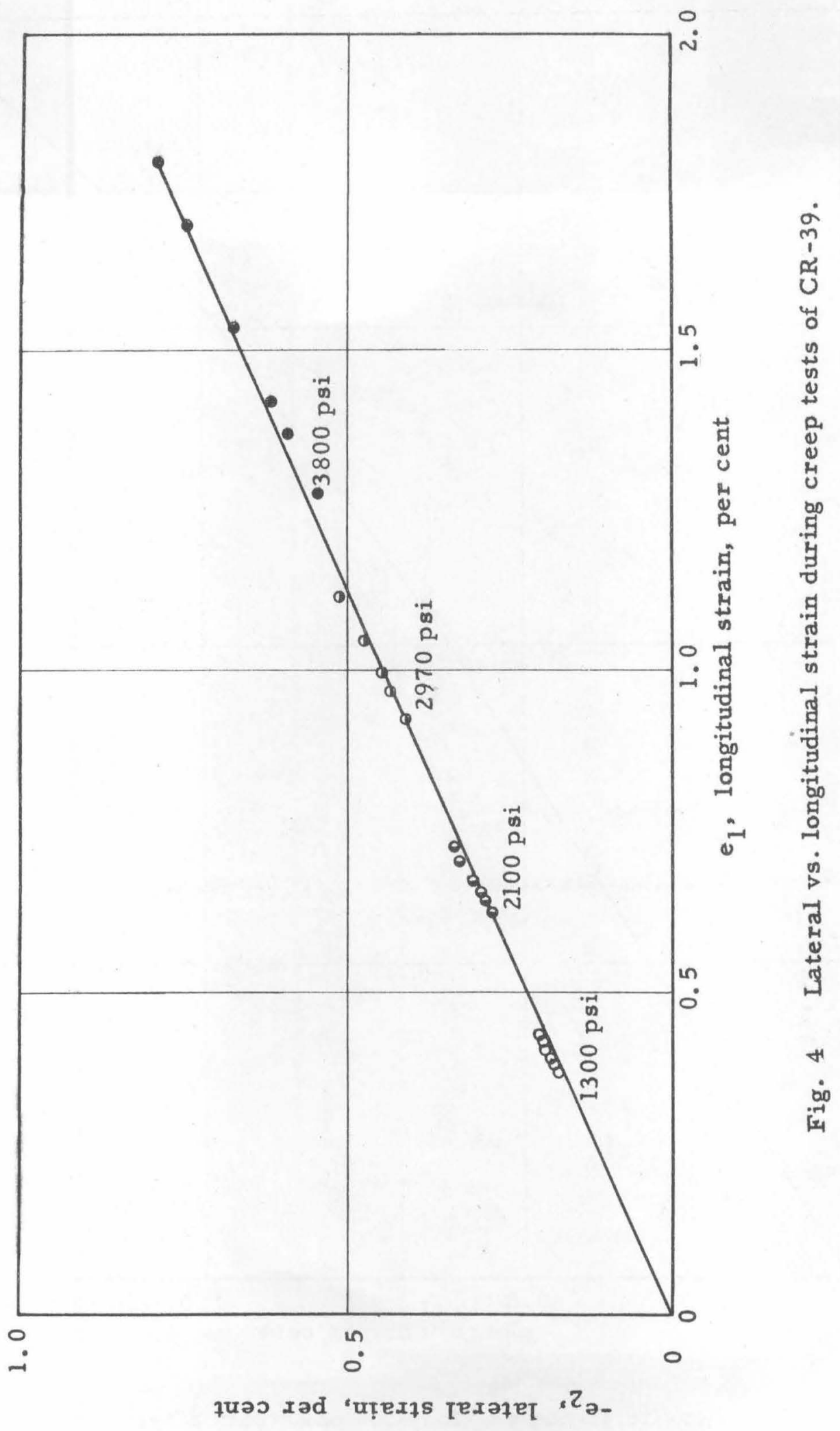




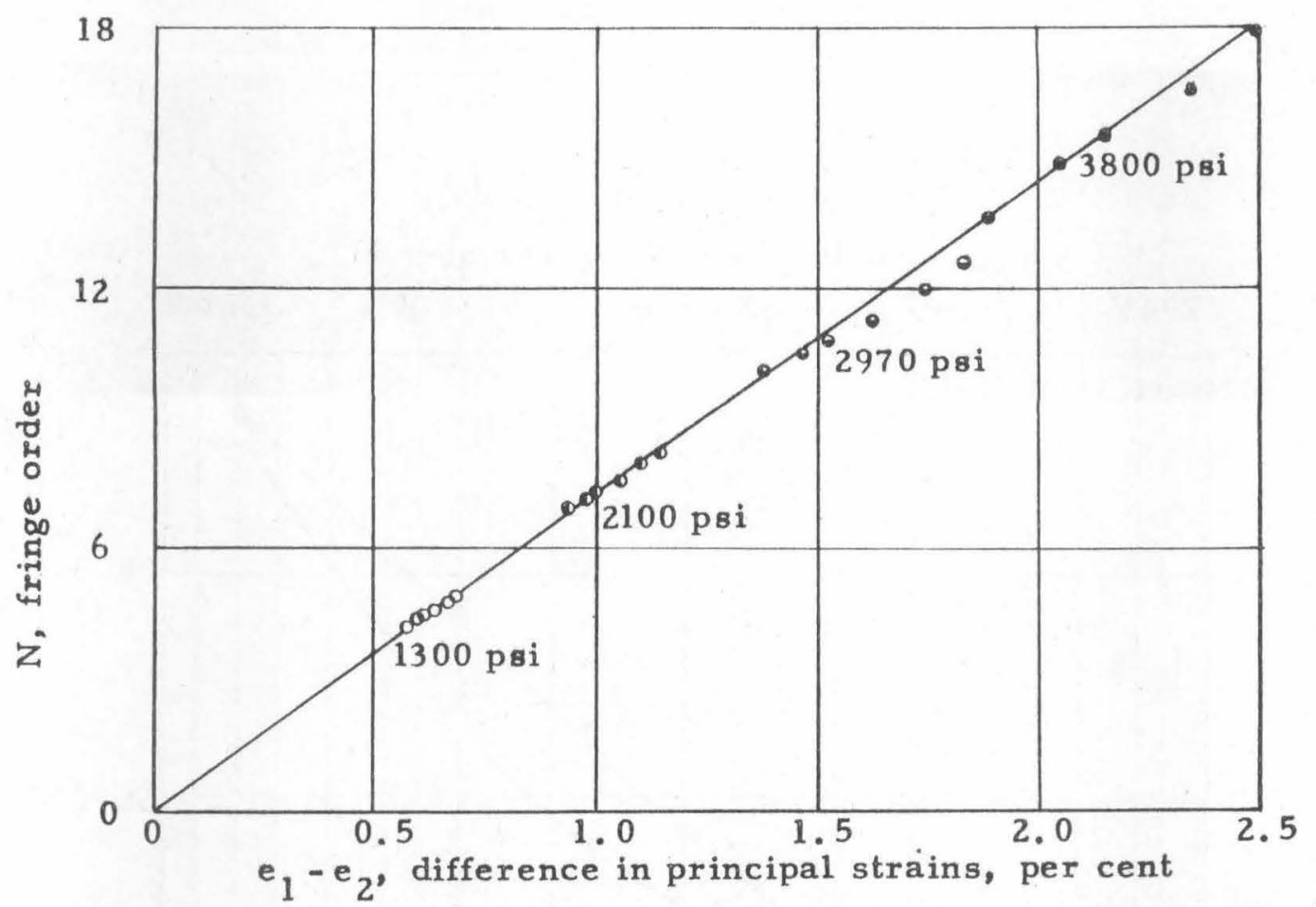

Fig. 5 Birefringence v8. strain during creep for CR -39

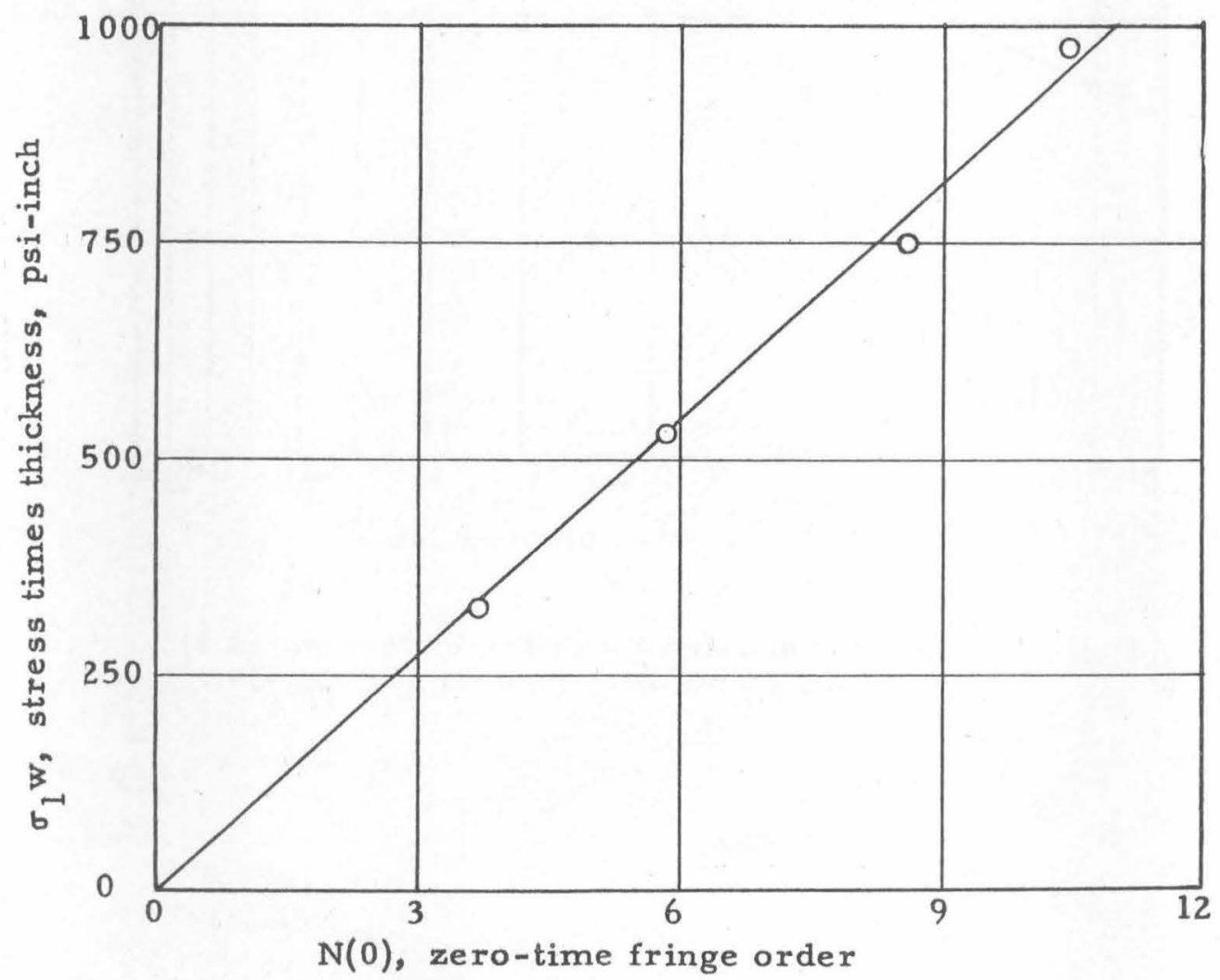

Fig. 6 Zero-time fringe order vs, stress for CR-39. 


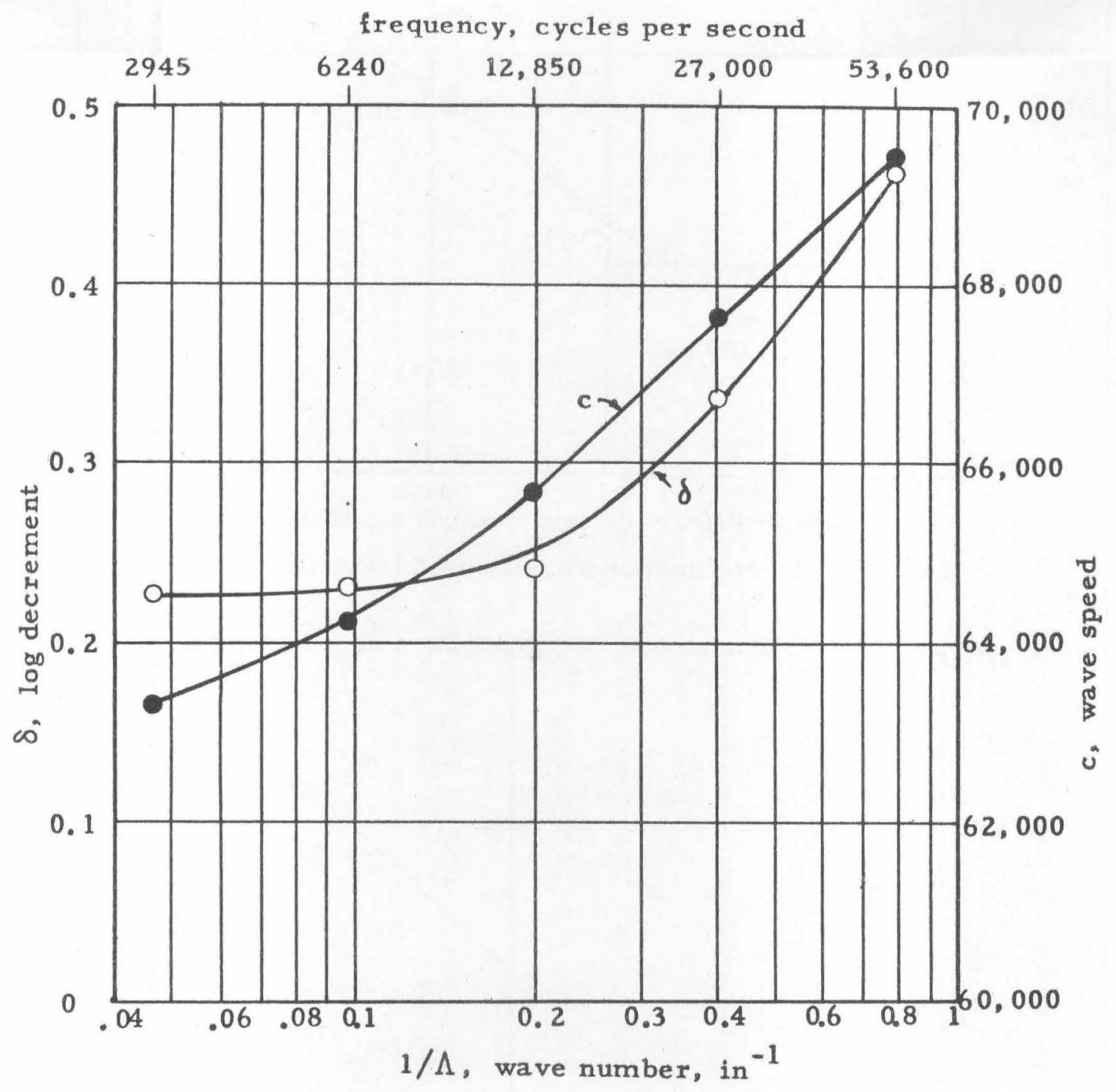

Fig. 7 Wave speed and logarithmic decrement vs. frequency and wave number for CR -39 . 


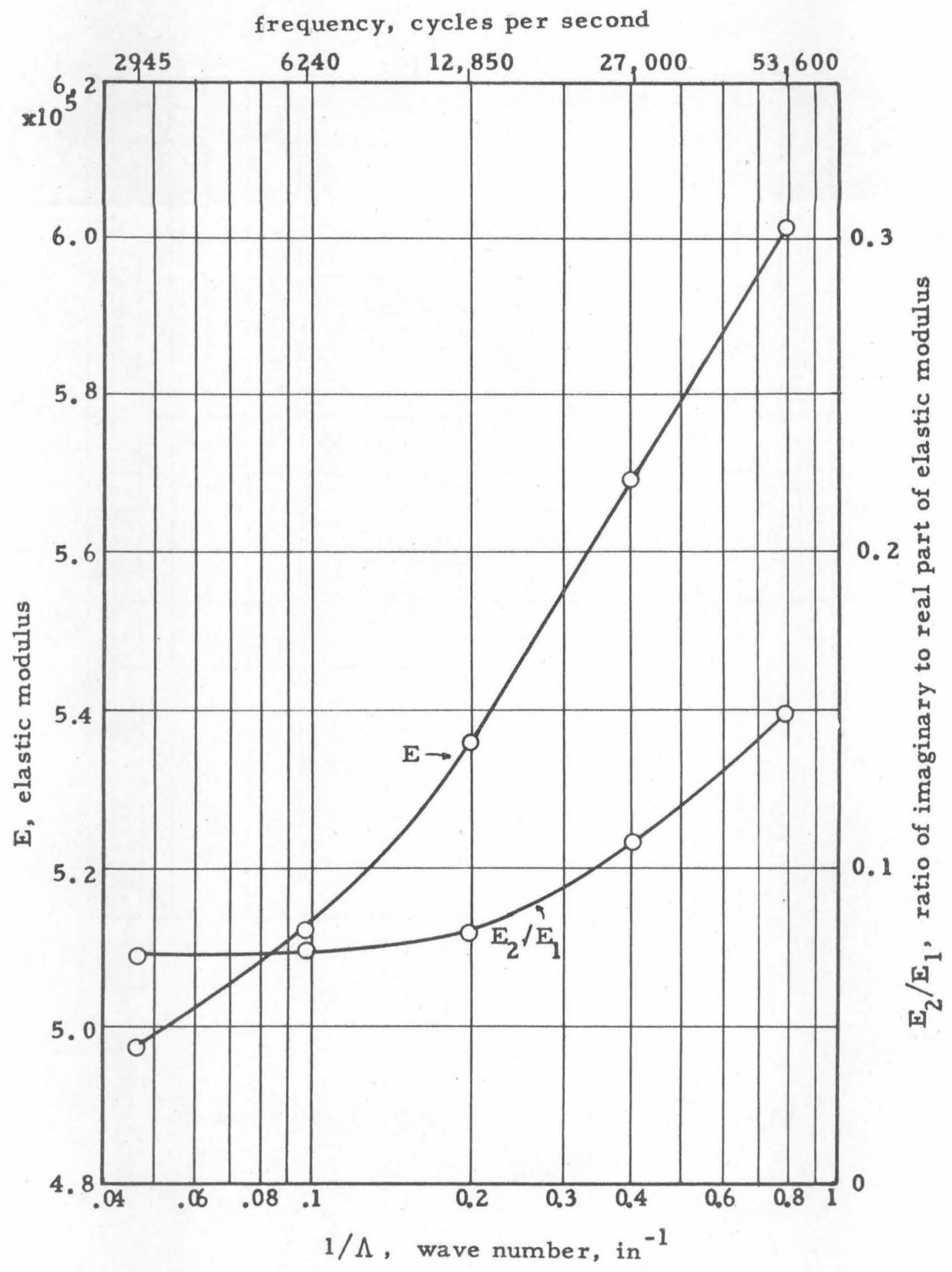

Fig. 8 Elastic modulus and ratio of real to imaginary parts of elastic modulus vs. frequency and wave number for CR-39. 


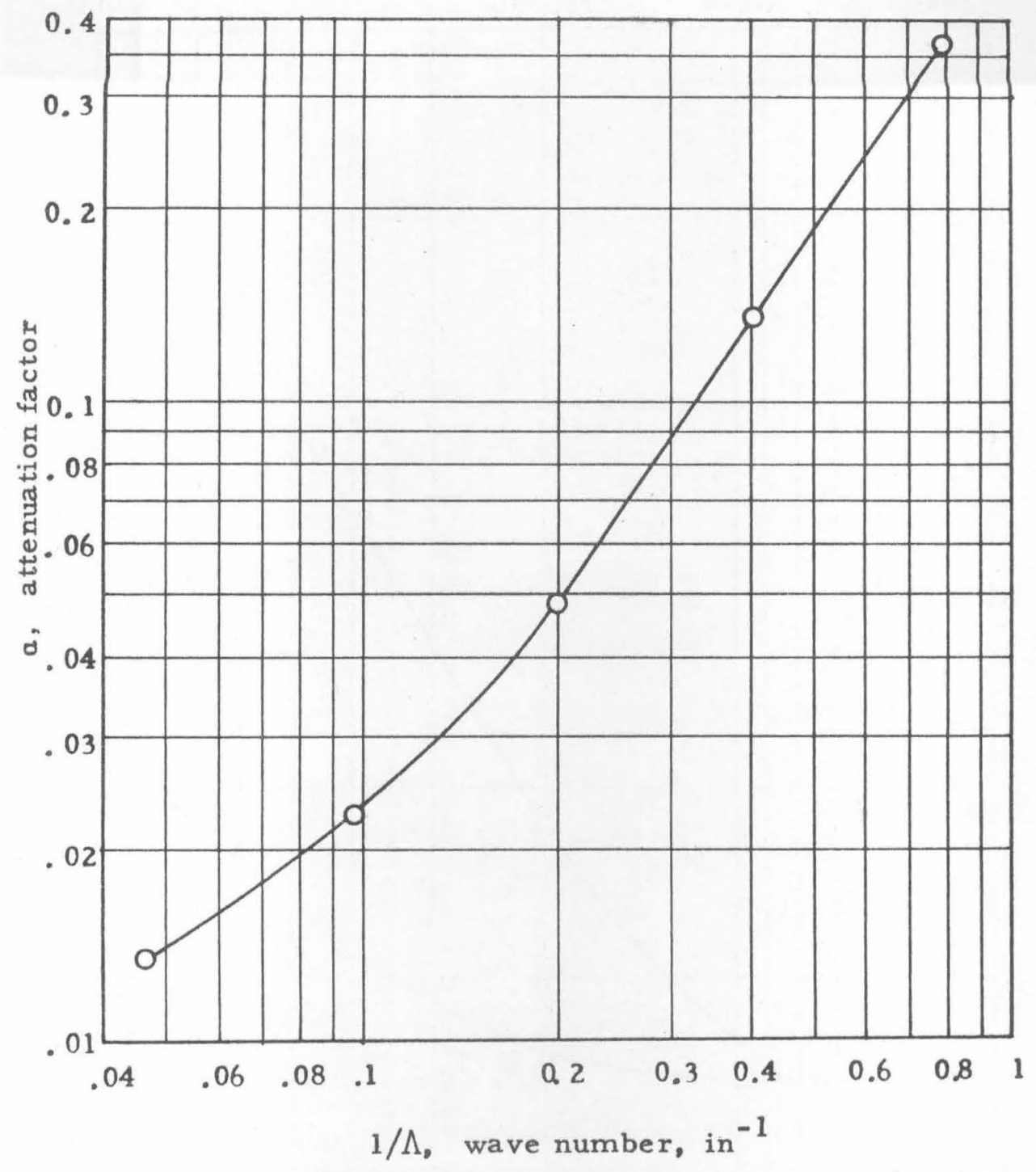

Fig. 9 Attenuation factor a vs. wave number 


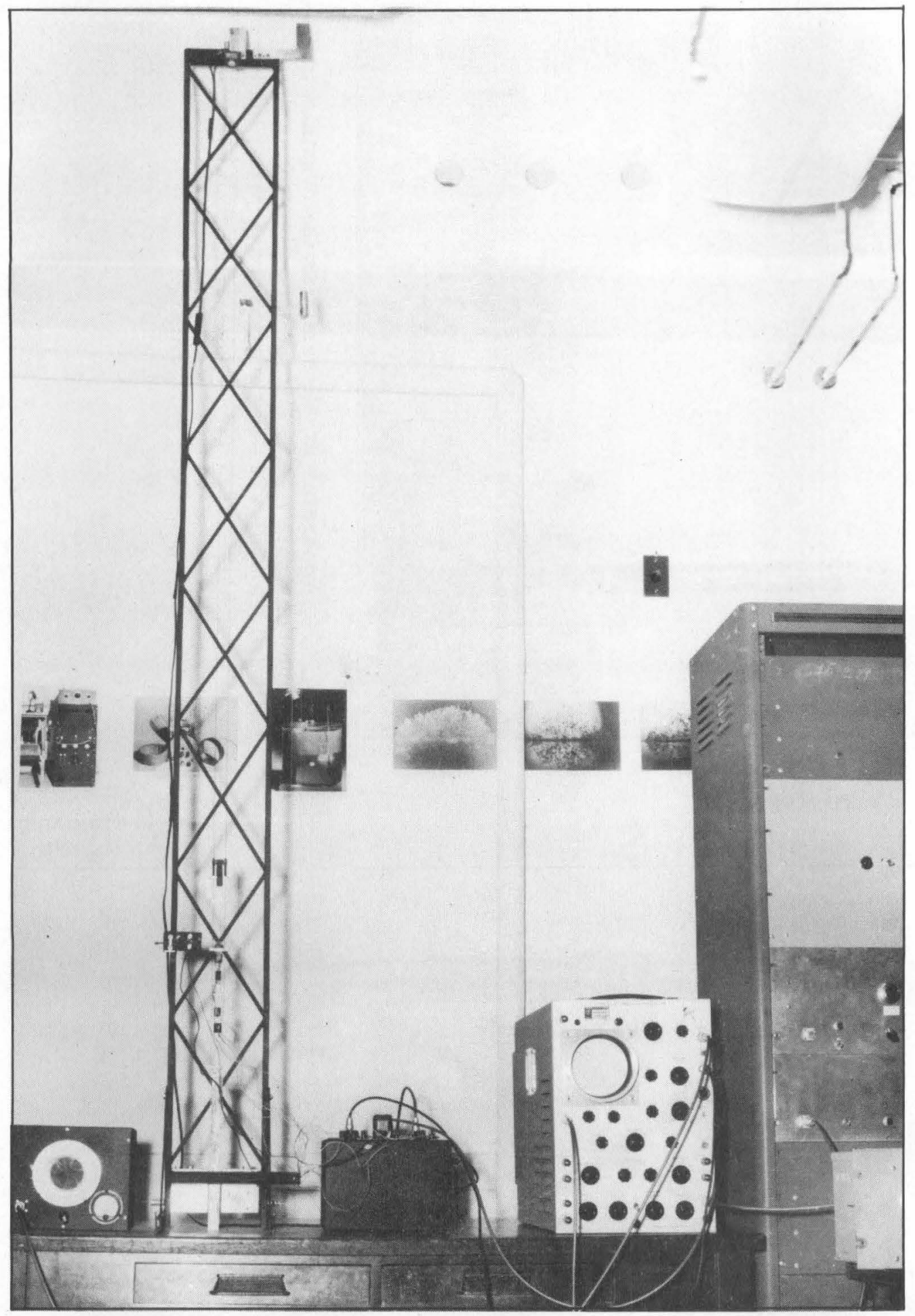

Fig. 10 Dynamic loading apparatus. Left: photomultiplier. Center: loading frame with wire strain gages cemented to the specimen. Right: strain gage bridge and oscilloscope. 


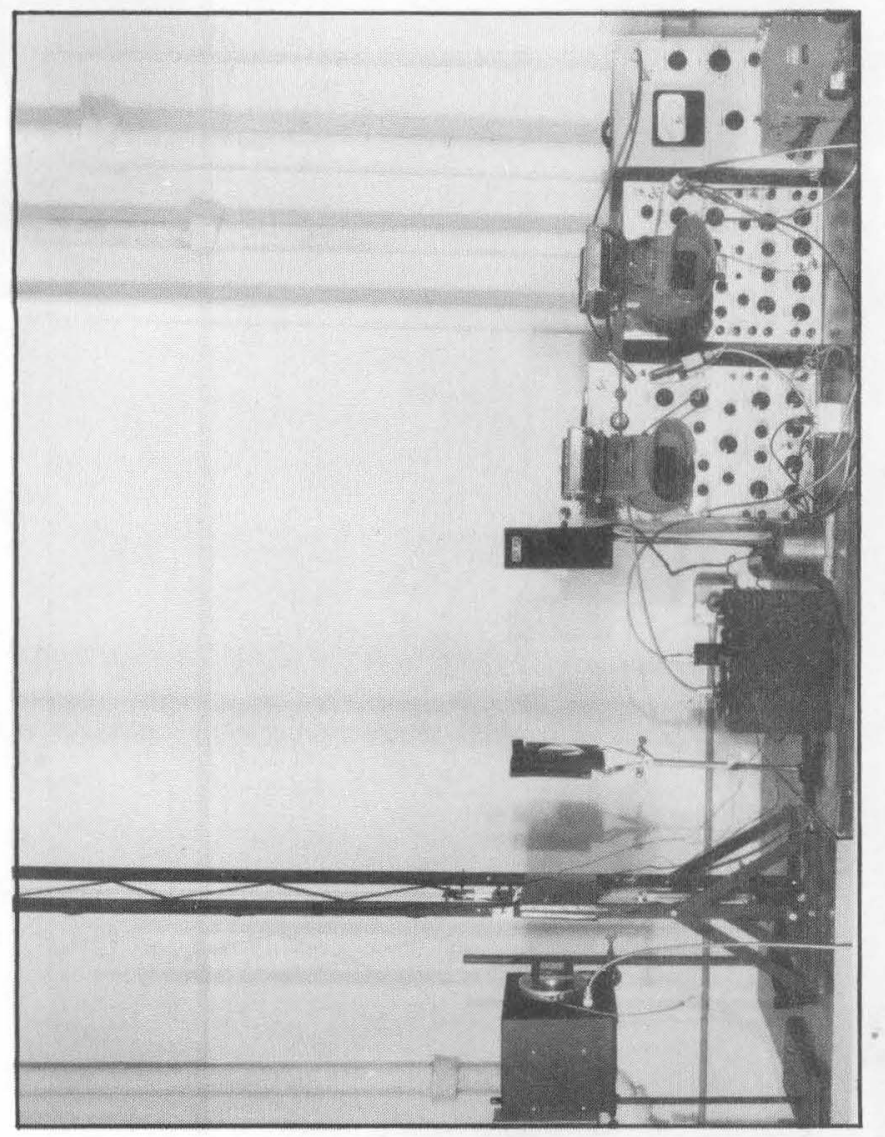

'

त

H오

ज 엄

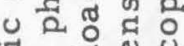

द् 4 ...

हैं क्

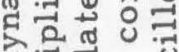

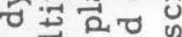

ข 3 ט ส

ॠ है $>$

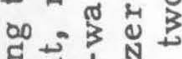

至 1 .

. द्व

어 올

西, o

गु

म- द व

영 व

of a

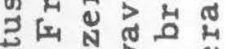

๙

ส

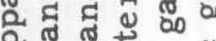

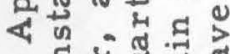
हี क्ष

N U

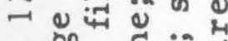

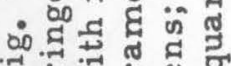

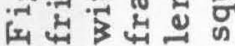

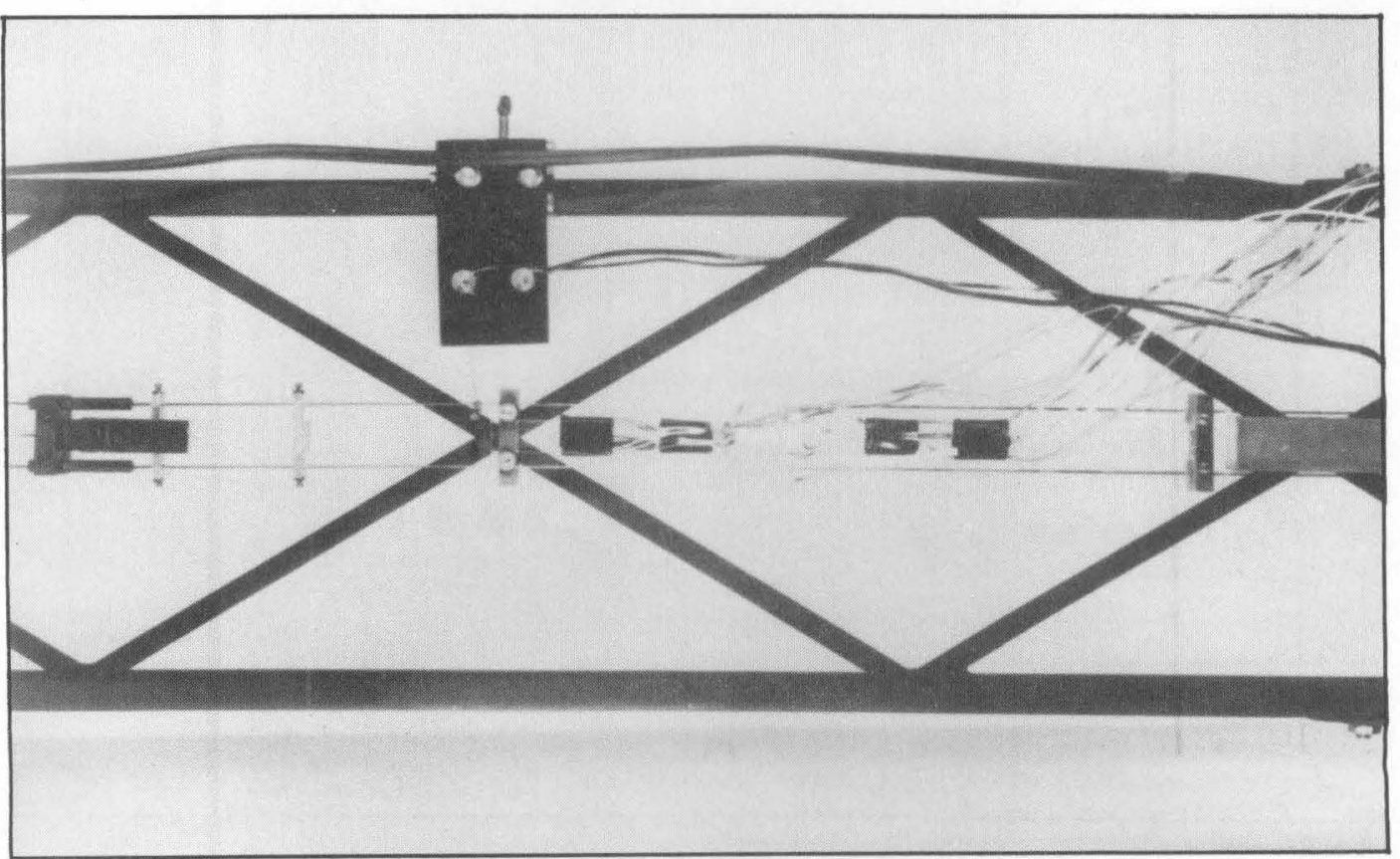




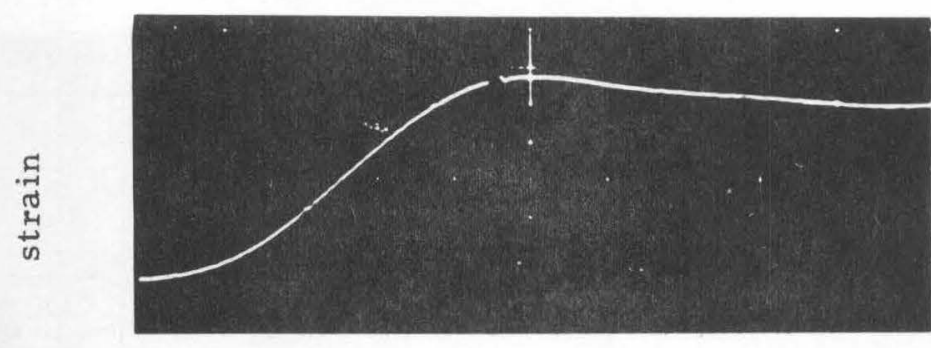

a
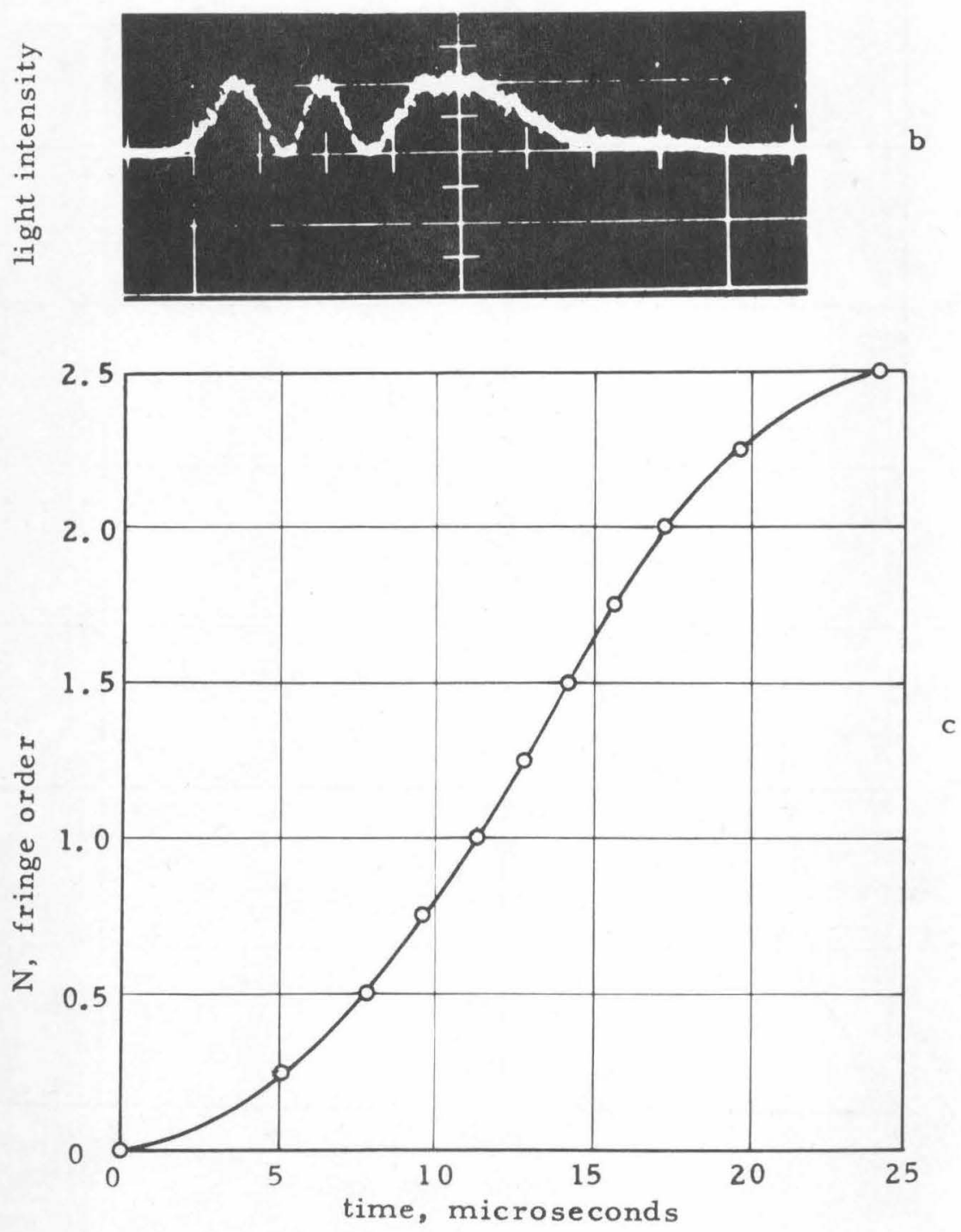

Fig. 13 (a) Oscillograph record of longitudinal strain on leading edge of stress wave, (b) oscillograph record of transmitted light, (c) fringe order vs. time, from (b). 


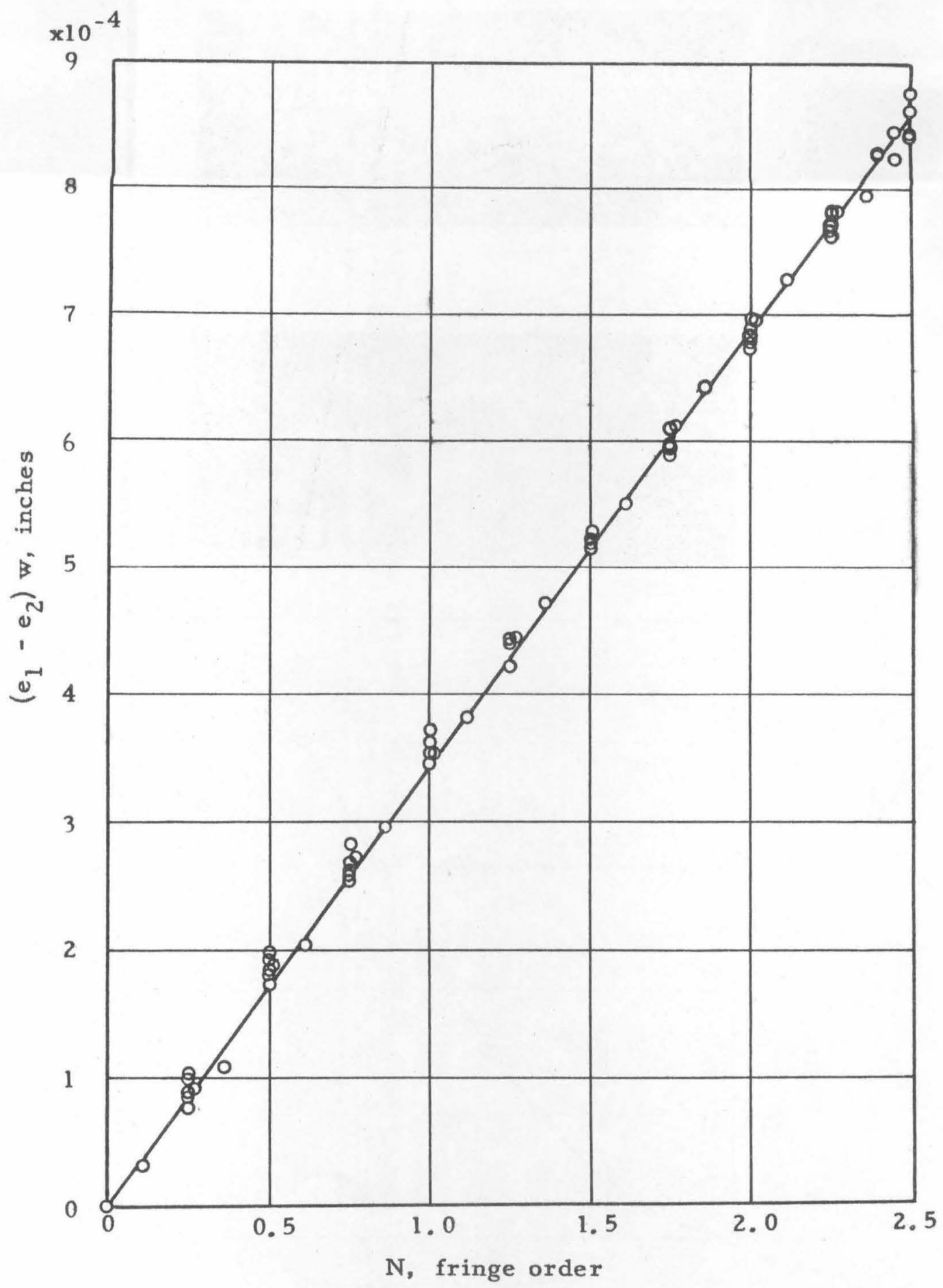

Fig. 14 Number of fringes vs. strain for leading edge of stress wave for CR-39. Eight runs. Light wave length $5461 \AA$ 


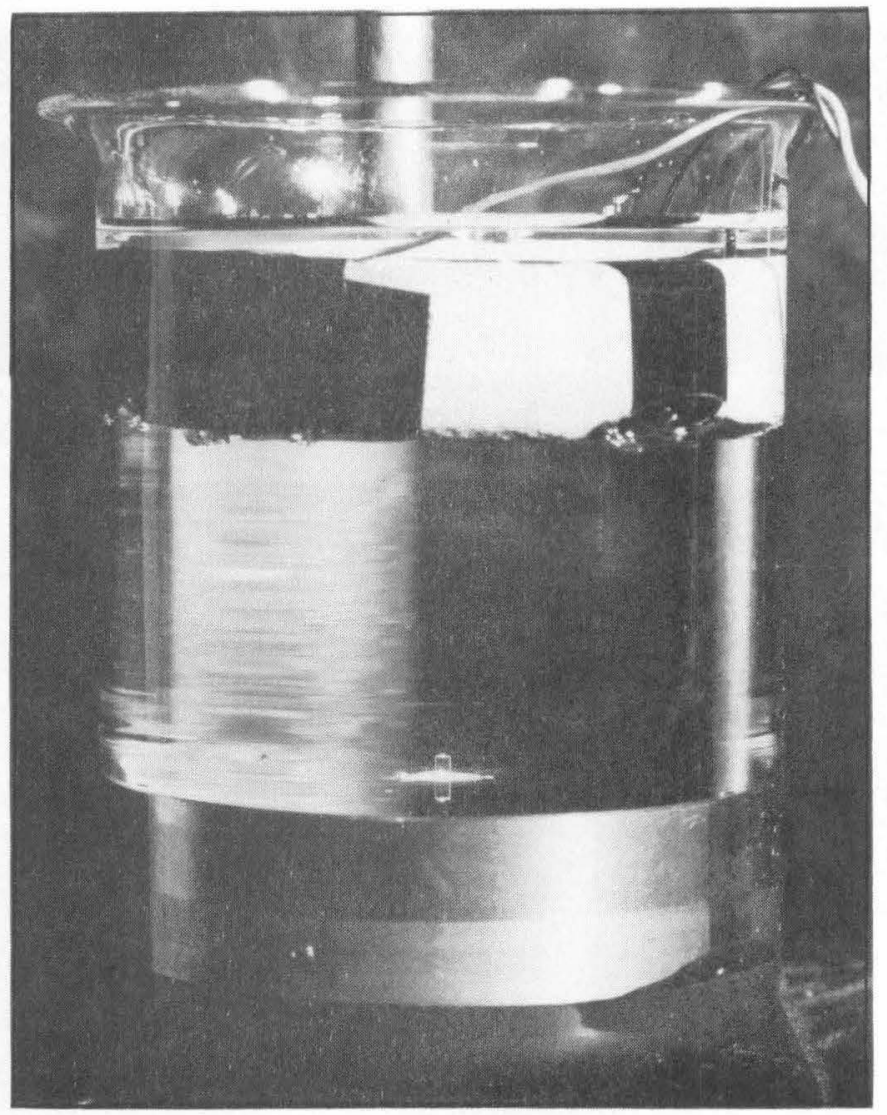

Fig. 15 Acoustic cavitation in water. A small bubble cloud can be seen on top of the photoelastic specimen.

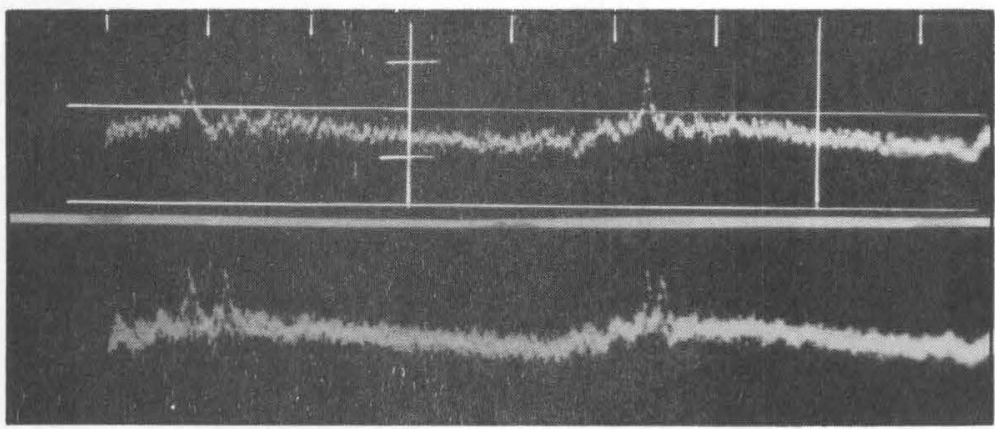

Fig. 16 Oscillographs of the light intensity through a $0.004 \times 0.004 \mathrm{in}$. slit centered $0.006 \mathrm{in}$. below the surface of a $1 / 16 \times 1 / 16 \times 1 / 8$ in. CR-39 specimen when cavitation is occurring. Horizontal sweep-time 10 microseconds per division. 


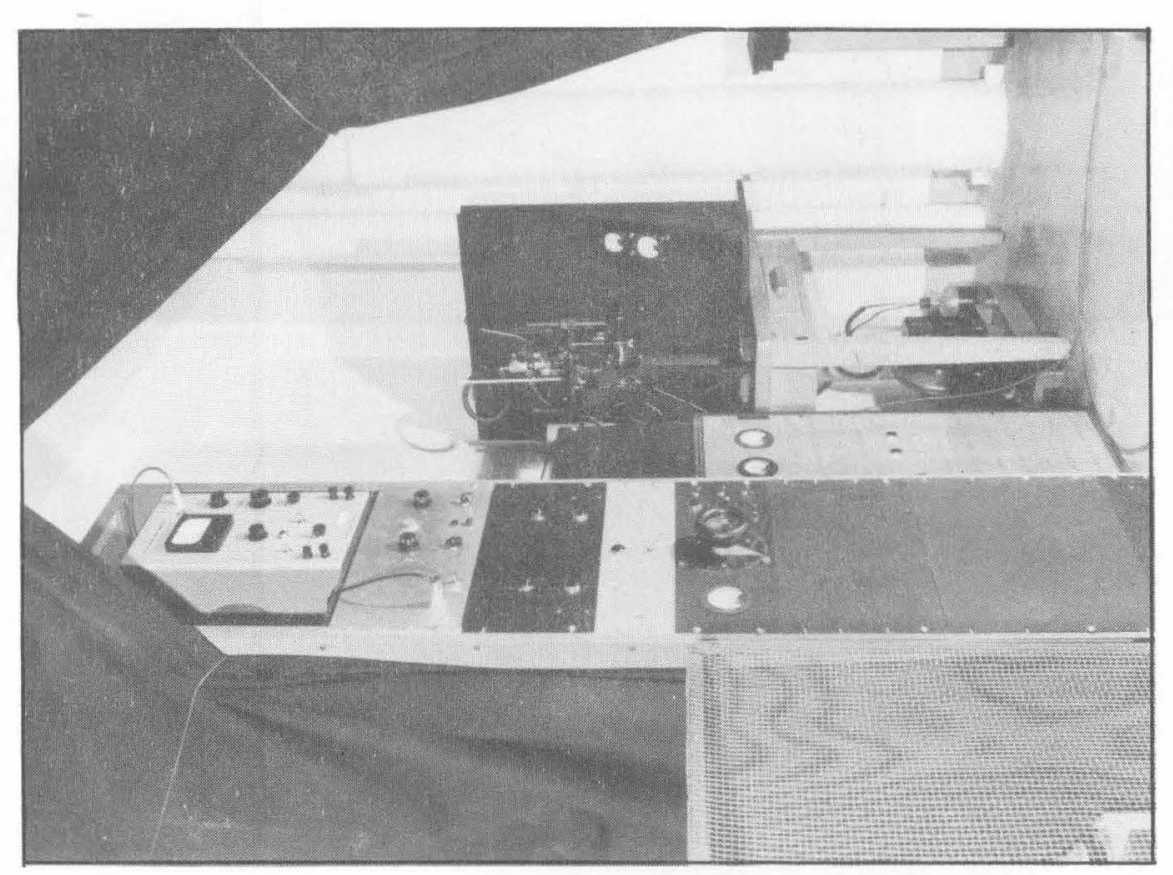

iे

永

ส

भ ज ज

क

(1) क م

मु.

उ. व

ह. త్త

द

ह 0 ह

ज山

द्व

ஏ

U $\ddot{\nabla}$ बै

号U

in

')

क o o

더 언 1. 위단

至范 Б告嵒

$\stackrel{\infty}{\infty}$

$\infty$

[4
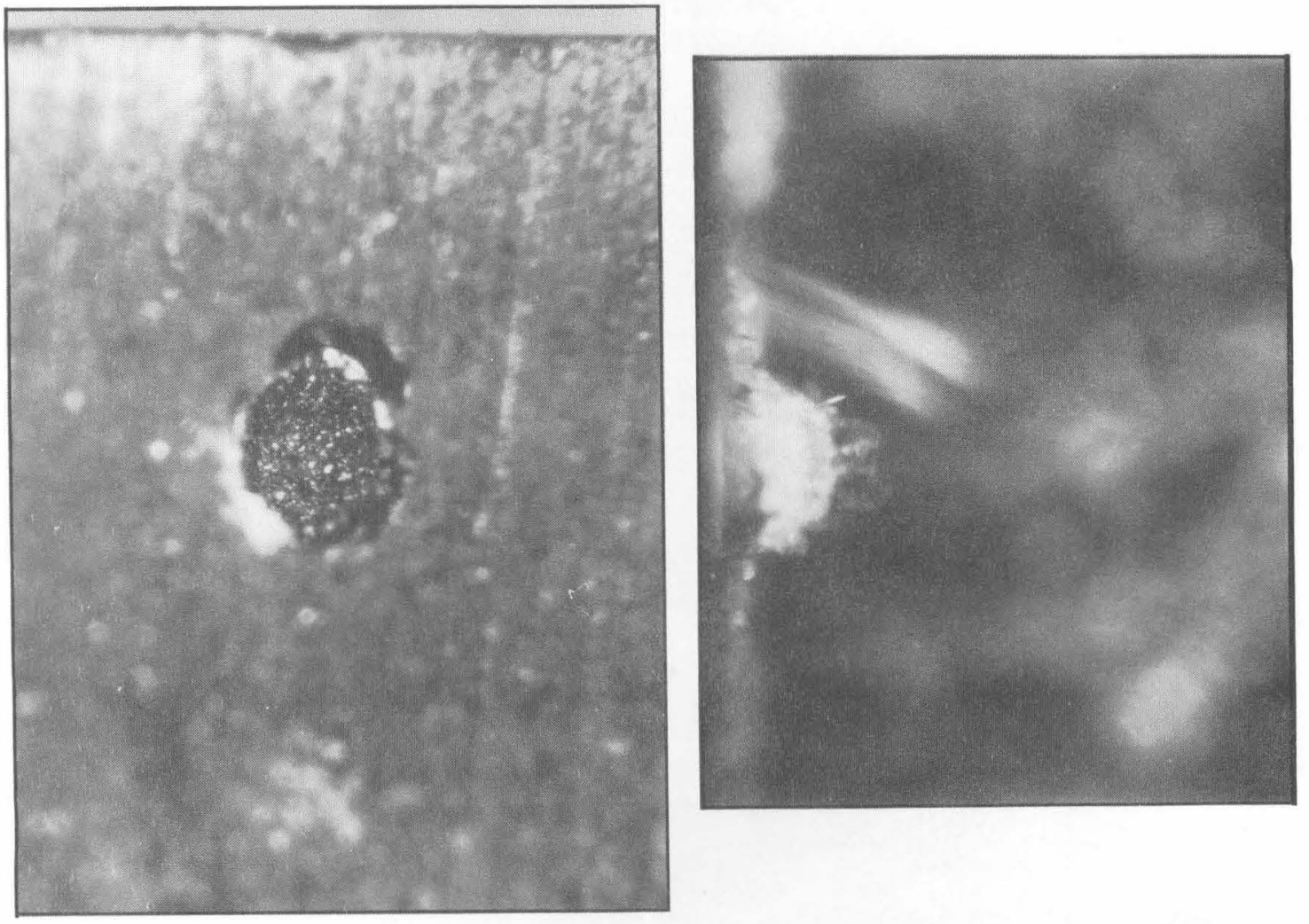

단

.

o n

$\underset{1}{ \pm}$

$x \cdot \frac{7}{\mathcal{E}}$

6

7 in

$\rightarrow \stackrel{4}{4}$

प्र

u

다 1

क व्.

(

0 प गु

Uै \&

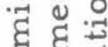

요

可

ब

I

$\infty_{i=1}^{\infty}$ 


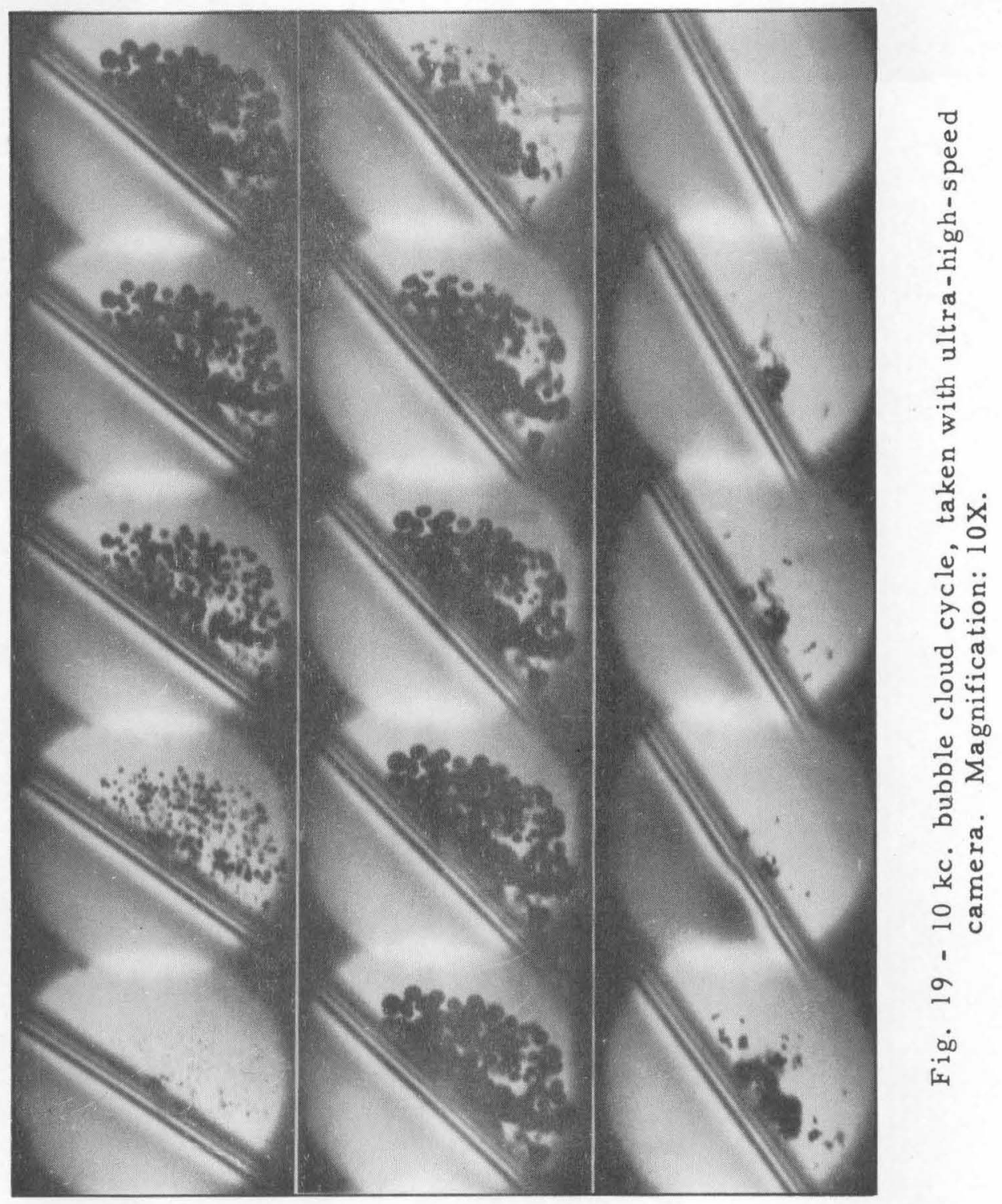



DISTRIBUTION LIST FOR UNCLASSIFIED

REPORTS ON CAVITATION

Contract Noonr-24420 (NR 062-059)

Chief of Naval Research

Navy Department

Washington 25, D. C.

Attn: Code 438

Code 463

Commanding Officer

Office of Naval Research

Branch Office

The John Crear Library Bldg.

86 E. Randolph Street

Chicago 1, Illinois

Commanding Officer

Office of Naval Research

Branch Office

346 Broadway

New York 13, New York

Commanding Officer

Office of Naval Research

Branch Office

1030 Eas氏 Green Street

Pasadena 1, California

Commanding Officer

Office of Naval Research

Navy 100, Fleet Post Office

New York, New York

Director

Naval Research Laboratory

Wa shington 25, D. C.

Attn: Code 2021

Chief, Bureau of Aeronautics

Navy Department

Washington 25, D. C.

Attn: Research Division

Aero and Hydro Branch (Code Ad-3)

Appl. Mech. Branch

(Code DE-3)
Chief, Bureau of Ordnance

Navy Department

Wa shington 25, D. C.

Attn: Asst. Chief for Research

(Code Re)

Systems Director, Under-

water Ord (Code Rexc)

Armor, Bomb, Projectile.

Rocket, Guided Missile War-

head and Ballistics Branch

(Code Re 3 )

Torpedo Branch (Code Re6)

Research and Components

Section (Code Re6a)

Mine Branch (Code Re 7)

Chief, Bureau of Ships

Navy Department

Wa shington 25, D. C.

Attn: Research and Develop-

ment (Code 300)

Ship Design (Code 410)

Preliminary Design and

Ship Protection (Code 420)

Scientific, Structural and

Hydrodynamics (Code 442)

Submarines (Code 525)

Propellers and Shafting

(Code 554)

Chief, Bureau of Yards and

Docks, Navy Department

Wa shington 25, D. C.

Attn: Research Division

Commander

Naval Ordnance Test Station 3202 E. Foothill Blvd.

Pa sadena, California

Attn: Head, Underwater Ord. Head, Research Div.
Commander

Naval Ordnance Test Station Inyokern, China Lake, Calif. Attn: Technical Library 
Commanding Officer and Director

David Taylor Model Basin

Washington 7, D. C.

Attn: Hydromechanics Lab.

Seaworthiness and Fluid

Dynamics Div.

Library

Commanding Officer

Naval Ordnance Laboratory

White Oak, Maryland

Attn: Underwater Ord. Dept.

Commanding Officer

Naval. Underwater Ordnance Sta.

Newport, Rhode Island

Director

Underwater Sound Laboratory

Fort Trumbull

New London, Connecticut

Librarian

U.S. Naval Postgraduate School

Monterey, California

Executive Secretary

Research and Development Board

Department of Defense

The Pentagon

Washington 25, D. C.

Chairman

Underseas Warfare Committee

National Research Council

2101 Constitution Avenue

Wa shington 25, D.C.

Dr. J. H. McMillen

National Science Foundation

$1520 \mathrm{H}$ Street, N. W.

Washington, D.C.

Director

National Bureau of Standards

Wa shington 25, D. C.

Attn: Fluid Mechanics Section

Dr. G. H. Keulegan

National Hydraulic Laboratory

National Bureau of Standards

Washington 25, D. C.
Director of Research

National Advisory Committee for Aeronautics

1512 H Street, N. W.

Wa shington 25, D. C.

Director

Langley Aeronautical Laboratory

National Advisory Committee for Aeronautics

Langley Field, Virginia

Mr. J. B. Parkinson

Langley Aeronautica1 Laboratory

National Advisory Committee for Aeronautics

Langley Field, Virginia

Commander

Air Research and Development Command

P. O. Box 1395

Baltimore 18, Maryland

Attn: Fluid Mechanics Div.

Director

Waterways Experiment Station

Box 631

Vicksburg, Mississippi

Beach Erosion Board

U.S. Army Corps of Engineers

Washington 25, D. C.

Office of Ordnance Research

Department of the Army

Wa shington 25, D.C.

Office of the Chief of Engineers

Department of the Army

Gravelly Point

Wa shington 25, D. C.

Commissioner

Bureau of Reclamation

Wa shington 25, D. C.

Director

Oak Ridge National Laboratory

P. O. Box P

Oak Ridge, Tennessee

Director

Applied Physics Division

Sandia Laboratory

Albuquerque, New Mexico 
Professor Car1 Eckart

Scripps Institute of Oceanography

La Jolla, California

Documents Service Center

Armed Services Technical

Information Agency

Knott Building

Dayton 2, Ohio

Office of Technical Services

Department of Commerce

Wa shington 25, D. C.

Polytechnic Institute of Brooklyn

Department of Aeronautical

Engineering and Applied Mech.

99 Living ston Street

Brooklyn 1, New York

Attn: Prof. H. Reissner

Division of Applied Mathematics

Brown University

Providence 12, Rhode Island

California Institute of Technology

Pasadena 4, California

Attn: Hydrodynamics Laboratory

Professor A. Hollander

Professor R. T. Knapp

Professor M. S. Plesset

Professor V. A. Vanoni GALCIT

Prof. C.B. Millikan, Director (1) Prof. Harold Wayland

University of California

Berkeley 4, California

Attn: Professor H.A. Einstein

Dept. of Engineering

Professor H. A. Schade,

Dir. of Engr. Research

Case Institute of Technology

Department of Mechanical Engineering Cleveland, Ohio

Attn: Professor G. Kuerti

Cornell University

Graduate School of Aeronautical

Engineering

Ithaca, New York

Attn: Prof. W. R. Sears, Director(1)
Harvard University

Dept. of Mathematics

Cambridge 38, Mass.

Attn: Prof. G. Birkhoff

University of Illinois

Dept. of Theoretical and

Applied Mechanics

College of Engineering

Urbana, Illinois

Attn: Dr. J. M. Robertson

Indiana University

Dept. of Mathematics

Bloomington, Indiana

Attn: Professor D. Gilbarg

State University of Iowa

Iowa Institute of Hydraulic

Research, Iowa City, Iowa

Attn: Dr. Hunter Rouse, Dir.

University of Maryland

Inst. for Fluid Dynamics and

Applied Mathematics

College Park, Maryland

Attn: Prof. M. H. Martin, Director

Prof. J. R. Weske

(1)

Massachusetts Institute of

Technology

Cambridge 39, Mass.

Attn: Prof. W.M. Rohsenow,

Dept. Mech. Engr.

Prof. A. T. Ippen,

Hydrodynamics Laboratory

Michigan State College

Hydraulics Laboratory

East Lansing, Michigan

Attn: Prof. H.R. Henry

University of Michigan

Ann Arbor, Michigan

Attn: Director, Engineering

Research Institute

Prof. V.L. Streeter,

Civil Engineering Dept.

University of Minnesota

St. Anthony Falls Hydraulic Lab.

Minneapolis 14, Minnesota

Attn: Dr. L. G. Straub, Dir. 
New York University

Institute of Mathematical Sciences 25 Waverly Place

New York 3, New York

Attn: Prof. R. Courant, Dir.

University of Notre Dame

College of Engineering

Notre Dame, Indiana

Attn: Dean K.E. Schoenherr

Pennsylvania State University Ordnance Research Laboratory University Park, Pennsylvania Attn: Prof. G.F. Wislicenus

Rensselaer Polytechnic Inst. Dept. of Mathematics Troy, New York

Attn: Dr. Hirsh Cohen

Stanford University

Stanford, California

Attn: Applied Math. and

Statistics Laboratory

Prof. P. R. Garabedian

Prof. L. I. Schiff, Dept. of Physics

Prof. J. K. Vennard, Dept. of Civil Engineering

Stevens Institute of $\mathrm{Technology}$ Experimental Towing Tank

711 Hudson Street

Hoboken, New Jersey

Worcester Polytechnic Institute Alden Hydraulic Laboratory

Worcester, Mass.

Attn: Prof. J. L. Hooper, Director

Dr. Th. von Karman

1051 S. Marengo Street

Pasadena, California

Aerojet General Corporation 6352 N. Irwindale Avenue

Azusa, California

Attn: Mr. C. A. Gongwer

Dr. J.J. Stoker

New York University

Institute of Mathematical Sciences 25 Waverly Place

New York 3, New York
Prof. C.C. Lin

Dept. of Mathematics

Massachusetts Institute of Technology

Cambridge 39, Mass.

Dr. Columbus Iselin

Woods Hole Oceanographic Inst.

Woods Hole, Mass.

Dr. A. B. Kinzel, Pres.

Union Carbide and Carbon Research Laboratories, Inc.

30 E. 42 nd St.

New York, N. Y.

Dr. F.E. Fox

Catholic University

Washington 17, D.C.

Dr. Immanuel Estermann

Office of Naval Research

Code 419

Navy Department

Washington 25, D.C.

Goodyear Aircraft Corp.

Akron 15, Ohio

Attn: Security Officer

Dr. F. V. Hunt

Director Acoustics Research

Laboratory

Harvard University

Cambridge, Mass.

Prof. Robert Leonard

Dept. of Physics

University of California at

Los Angeles

West Los Angeles, Calif.

Prof. R.E.H. Rasmussen

Buddenvej 47, Lyngby

Copenhagen, Denmark

via: ONR, Pasadena, Calif. (1) 